\title{
Research on the Education Mode of the Food and Drug Safety Police
}

\author{
Qin Wei \\ Department of Public Security \\ Hubei University of Police \\ Wuhan, China 430034
}

\begin{abstract}
The problem of food and drug safety is related to people's health and life. Currently, China has established with the pharmaceutical administration law as the core of administrative rules and regulations system, the key is how to implement in order to form a drug safety supervision system with Chinese characteristics. Police drug safety law enforcement stands at the height of about stability, giving full play to the advantages of the era of big data information and technology, and constantly improves prevention and treatment ability of the food and drug safety, to strengthen the construction of drug safety risk prevention and control system and crack down on the food and drug crime. Talent team is the basis of doing a good job of food and drug crime prevention. Therefore, how to cultivate a reasonable professional knowledge structure with good quality medicine is important and it is an urgent problem we are facing. We should explore how to build a drug police,a relatively new launching professional applied talents training mode according to the requirements of talent training and orientation, curriculum setting and other aspects such as innovation supporting measures.Keywords - the food and drug safety police ; education mode; innovation.
\end{abstract}

\section{INTRODUCTION}

Party's eighteen big meetings held in 2012, the CPC central committee to focus on the implementation of "food and drug safety strategy" decisions, such as food and drug safety work was promoted to a new strategic height. Food safety crime, is refers to the violation of the relevant provisions of the "food safety", according to the criminal law needs to be investigated for criminal responsibility according to law. Major food and drug safety accidents occurred constantly in recent years, such as "poisonous milk powder", "gutter oil", "clenbuterol", "plasticizer", etc, lead to questions of national food safety guarantee system. Since 2013, after a long brewing, from central to local, successively set up specially to crack down on the crime of Food and Drug Safety Police(FDSP). The nationwide, to combat the illegal crime of food and drug administration of the establishment of the professional law enforcement team, embodies the public security organ shall actively adapt to the requirement of promoting the modernization of national management system and management capabilities, starting from the source to the food and drug safety for effective prevention and control crime.
In Britain and the United States and other developed countries over the past 20 years was substantial cut in the Food and Drug safety supervision work of the administrative personnel, and gradually increase the Food and Drug safety regulation technology and professional law enforcement officers to crack down on the Food and Drug crimes, such as the United States Food and Drug Administration ( FDA). The agency not only value through chemical, medicine, pharmacology, and food engineering field from technology for efficient scientific support, and more equipped with tens of thousands of wearing uniforms and equipped with advanced instruments weapon's law enforcers in the manufacturers, merchants, market a line inspection tour, so as to find problems in a timely manner, initiative quickly. At the same time, the western developed countries for the food and drug safety police attach great importance to the cultivation of professional talents and emphasizing practical and vocational training mode. In comparison, China's food and drug safety management in the aspect of professional technology and the law enforcement appear behind with thin and leading the administrative personnel, professional and technical personnel and professional law enforcement personnel proportion is low. According to the statistical data show that in 2011 China's food and drug supervision and management system of the administrative staff of about 53000 people, professional and technical personnel and professional law enforcement has only 30000 people, the whole system of staff hold professional inspection qualification only 15000 people. In addition to the personnel structure rendering is not scientific, the imbalance phenomena such as not professional, in law enforcement efforts and normative also has many problems. For example, although the food and drug supervision and administration departments in every region of the cases are equipped with a special illegal food and drug safety inspection force, but in the actual law enforcement operations should be case rarely handed over to judicial organs, widely exists in the administrative punishment measures in place of criminal judicial punishment measures. This not standardize law enforcement is the most direct consequences to reduce the cost of food and drug safety illegal and criminal behavior and overall weakens the crime crackdown on such food and drug safety. But everywhere of the food and drug safety accident happened in recent years and was exposed by the media and public safety problems in this field questions or even panic, to crack down on food and drug safety in the 
field of crime so as a new public security problems on governance agenda, and the public security organ in the entire management system was given priority to crack down on the crime of food and drug safety activities.

Food and Drug Safety Police (FDSP) puts forward new requirements to talents training in the police force. As the main sector of the public security personnel training, the public security colleges and universities must think seriously about how to keep up with the new requirements and new launching Settings, developed countries should draw lessons from and study related to the cultivation of the professional law enforcement team and constitute a pattern, also want to together with the present situation of China's food and drug administration and the reality of public security, exploration, innovation, big data background, talent of education high quality, innovative social governance, improve the social service ability.

\section{FOOD AND DRUG SAFETY POLICE (FDSP) TRAINING MODE DEMAND AND LOCATION}

\section{A. Food and Drug Safety Police (FDSP) Training Mode}

The food and drug safety police personnel training mode in the food and drug launching talents training objectives as a guide, with specialty course system and teaching content as the foundation, According to the food and drug safety crime prevention and control work of the job in the basic diathesis, theoretical knowledge, practical ability and so on the coordinated development of the specific requirements, to build both can meet the demand of social public security, also conforms to the student individual growth and development regularity of an education or teaching mode. To measure the standard of professional applied talents cultivation model is scientific or not mainly refers to the training of talents in this mode is in line with the needs of social governance and public safety. In the current situation, the food and drug safety police apparatus of the guiding ideology of the applied talents can be expressed as follows: On the basis of the basic qualities, to the food and drug launching position matching work ability as the center, make the professional theory and real practice teaching, the police colleges and universities a gleam of choose and employ persons and the security department, the classroom learning and social practice, academic education and vocational training mutual confluence, to build a multiple-layered professionals

The current all kinds of illegal and criminal defense against public food and drug safety chain concealment, diversity, strongly professional, this would require the food and drug police more professional recognition in the food and drug illegal crime, identification and appraisal ability; But also to understand the information age a new detection method, achieve detective work involves special general grasp of computer integrated technology and application, and then through the scientific identification, information investigation and all kinds of technical means and professional law enforcement to prevent and crack down on food and drug crime. All in all, combined with the needs of society and the launching major characteristics, the food and drug safety police talent cultivation model to realize training objectives should be.

\section{B. Food and Drug Safety Police (FDSP) Personnel Training Mode}

In order to ensure food and drug safety management and law enforcement personnel's quality of education, food and drug safety police training mode should pay attention to the following basic link: Clear talents training target and norms; Strengthen professional construction and reform; Optimize the curriculum system and teaching content; Attaches great importance to the ability and quality training; Reform teaching methods and teaching means; Advocating integration for teaching and scientific research; Improve the internal quality monitoring and security system. At the same time, we should reflect the characteristics of the public security colleges and universities, through the training mode innovation, combined with the food and drug safety criminal cases in the field of working practice, learning from training ideas, professional structure, mechanism, the training object, content, form, teachers and other aspects of security, work areas, break down barriers between professional disciplines, with individual ability as the standard design course, And the innovation to adapt to the social changes of flexible, situational type personnel training mode, by promoting student groups individual learning initiative and enthusiasm, synchronous improve students quality, overall quality, realize the applied talents training goal. (The figure below is the exact.) "Fig. 1"

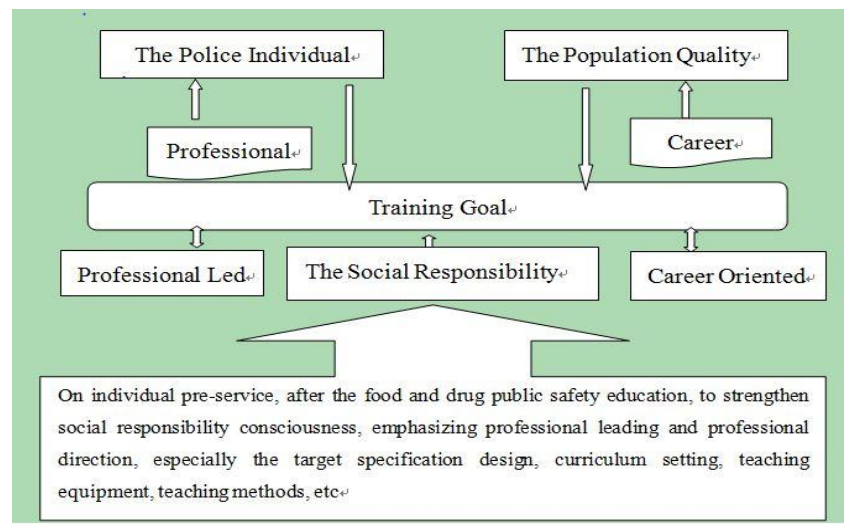

Fig. 1. The training mode for food and drug safety law enforcement

The training mode of qualified food and drug police personnel to have good political quality, legal quality, professional quality, physical quality, psychological quality, has a strict organizational discipline concept and good professional ethics, master the basic theory of criminal investigation system, basic knowledge and basic skills, be familiar with the policy and law, with strong practical ability and innovative spirit, for economic crimes investigation, the food and drug, food and drug supervision and management, public security and criminal investigation department senior applied talents. They are designed for the food and drug illegal crime of launching, the future will become especially strong fist to the food and drug crime, make the administrative law enforcement and criminal investigation 
can organic link, and eliminate the regional boundaries, formation of the full range of food and drug safety supervision, hit the normal mechanism of all aspects of the security work to develop more efficient food and drug safety. On the cultivation of talents to clear the professionalism of the food and drug safety crime prevention and combat work will involve food science, microbiology, medicine, chemistry, basic law and other related disciplines, at the same time also need to strengthen investigation skills and the law enforcement quality, psychological quality of comprehensive training.

\section{FoOD AND DRUG SAFETY POLICE (FDSP) TRAINING MODE OF CURRICULUM SYSTEM SETTINGS}

Throughout the construction of personnel training mode, the design of the curriculum system and teaching content of the selected is a very important content. Therefore, the establishment of curriculum system of the system is to build one of the key link of cultivating talents, and system of the professional curriculum system construction mainly involves the professional theory knowledge teaching, experiments teaching, topic discussion, regulators, the public security departments, a lot of link such as department internship related production enterprises.

\section{A. The Key to Personnel Training Mode, Course System of Basic Design}

Mainly includes: pay more attention to the general education of police professional education, build "basic unity, especially after pass first, dedicated, professional deepen" curriculum system. The entire curriculum system according to the different nature and characteristics of curriculum can be divided into professional core courses of public basic course, public security, public security professional direction course, experiment, practice and so on five big modules.

First of all, the public foundation course generally divided into three aspects: (1). Political Theory and Professional Ethics Theory, such as the Principles of Marxism-Leninism, MAO Zedong Thought, Deng Xiaoping Theory, Political Economics, etc; (2). With the core of computer use English listening, Speaking and Writing ability of common base class curriculum; (3). The legal basis for classes, the legal basis for here mainly includes Introduction to Law, the Constitution, the Criminal Law, Administrative Law, Civil Law and other courses, especially focus on the Public Security Criminal and Administrative Law Enforcement Procedures and Norms, Food and Drug Safety Management related laws and regulations.

Second, professional core courses include: the Food and Drug Knowledge, the Food and Drug Identification, the False and Inferior Food and Drug Crime Investigation, the Food and Drug Ring Safety Regulations Interpretation, Sham Tort Food and Drug Crime Investigation, Environmental Crime Investigation, Interview Skills, course content such as the Internet Survey and Computer Forensics. These courses setting goals is to develop the food and drug safety police station should have the ability to: on the one hand, including improving the recognition of fake and shoddy food and drug, on the other hand, the food and drug police will continue to improve under current information era to the food and drug safety investigation in criminal cases. In food and medicine specialized core curriculum should focus on the implementation of case teaching, establish categories according to the requirement of the teaching goal is complete putted forward, the processing and analysis system is designed, so that the students through to the food and drug safety analysis, synthesis and evaluation of illegal and criminal cases to strengthen the professional knowledge learned, to improve in the future work will meet all kinds of uncertainty risk forecast and affordability.

Third, professional direction course in public security study, investigation, relevant public security on the basis of professional disciplines of law, set up the Basic Theory of the Public Security, Public Security Management, the Introduction to the Science of Criminal Investigation, the Criminal Investigation Technology, the Public Security Organ for Administrative Case Program Regulations, The Program Rules for the Criminal Cases Handled by the Public Security Organs, Public Security Informatics and so on public security professional courses.

Fourth, the experiment is mainly for the food and drug (also can add environmental circumstances) basic safety inspection, appraisal aspects of experimental teaching courses. Arrange course includes three parts: The first part, food analysis. Mainly from the food hygiene, food, pesticide residues, food additives, food safety standards were introduced from the aspects such as quality inspection. The second part, drug analysis. Including pharmacy, fake and inferior drugs detection, near infrared detection, reagent rapid detection methods. The third part, the environmental monitoring. Mainly include the environment, atmosphere, soil water pollution testing method, based on the analysis of mineral elements extracted from all kinds of different environment, to detect the environment is severely contaminated, and the basic type, grade and status of contamination. Experiment samples can be directly in the market of random sampling, and then through the experiment to test whether the pork with clenbuterol, meter whether containing sulfur dioxide, protein, fat content in milk powder is meet the national industry standard, whether to contain three gather hydrogen ammonia and other harmful ingredients, cooking oil, whether there are carcinogenic aflatoxin, whether liquor blending industrial alcohol, identify if the food is honey, pigs, duck blood, test drugs such as active ingredients, harmful ingredients and raw materials, etc In short sample selection is a series of experiment and daily life quality is closely related to security issues by the public, and strict with the students in learning knowledge after a certain experiment independently.

Finally, the practice is a very key teaching link in the teaching, through strengthening practice teaching and training can effectively improve students' professional skills. To completely change the practice is attached to theory teaching of professional this independence is poor, weak, to design a comprehensive training plan, training outline, and scene simulation, case simulation, department internship practice class, such as proportion increased to account for 
about $40 \%-50 \%$ of the total teaching hours, gradually establish a relatively independent practice teaching system. Must clear talent training is the purpose of the process, so be sure to implement the vacations, internship arrangements for the student to the food and drug production enterprise practice. Through the internship students practice to strengthen education training department to communicate with a line of enterprise cooperation with law enforcement agencies, truly realize the field of professional training and the social front demand seamless docking.

\section{B. The five Course Module Settings and Proportion}

The five modules in the curriculum system is in full accord, because of their different features and functions, in the course system in different position, so should be on the arrangement of the school and the allocation proportion. Is the foundation of public basic courses focus on training quality and logical thinking, legal judgment, writing instruments, such as general ability. Professional core courses and professional direction course aimed at training basic ability, the law enforcement quality and job skills. Curriculum system of the first four plate press 4:3:2:1 class proportion distribution, namely the public foundation course class accounted for $40 \%$, core curriculum classes $(30 \%)$, professional direction course accounted for $20 \%$, the experimental course accounted for $10 \%$. The proportion of all theory teaching and practice teaching should be gradually achieve to $1: 1$.

\section{TO ADAPT THEMSELVES TO THE NEW PERSONNEL TRAINING MODE OF INNOVATIVE MEASURES}

Food and drug safety police professional talents cultivation is a systematic project, the intended target of the background to achieve reform, and must have the system supporting measures, from the education idea and the practice teaching system, teaching evaluation standards, selection of teaching staff and the professional investment and so on carries on the comprehensive reform and innovation.

\section{A. To the Concept of Education Innovation}

From the concept of education, we should value theory from the past, neglecting the application out ideas, to adapt to the needs of the development of society, this is the basic rule of education. The process of training talents to the advanced means, thinking science and quality control. All the school system to serve for the teaching, the school is also a small society, realize the total quality management and quality guarantee system. Not only to cultivate professional ability strong technical and practical future police, more should guide students to use professional, to participate in more social activities, enhance their sense of mission and sense of responsibility. Through the public welfare activities, to make students more deeply feel the food and drug safety is related to the life and health and safety, from the perceptual and the rational constantly strengthen the awareness of social responsibility.

\section{B. Pay Attention to the Teaching Content, Method and Means of Innovation}

In the teaching in addition to the traditional detection method or technology to teach, also pay attention to the innovation of the teaching content. We should combine "Internet + ", explore the innovation of the teaching content and method of professional student, pay attention to improve students' ability construction. Let students understand not only the leading edge of the food and drug safety management, and greatly improve students' learning interest and initiative in vocational skills.

\section{Teaching Evaluation Criteria Should Be Innovative}

Must set up on the basis of quality, new education quality and learning quality based education. Teaching evaluation criteria has two aspects, on the one hand, is to teacher's evaluation, on the other hand is a evaluation of student achievement. Comprehensive evaluation should emphasis on the evaluation of peer experts already, also want to emphasize student evaluation. To change the assessment of the evaluation of student achievement and pure in the final written examination as the only standard of evaluation way, must set up post ability as the standard of assessment methods. Especially to research how to undertake to the student professional ability tests, and finally to issue the approval certificate of competency level.

\section{Teachers to Innovate}

Change the way of traditional teacher, must develop "double type" teachers. By constantly improve their professional accomplishment and teaching research topic to improve their practical ability and teaching ability. Can according to need to hire a public security organ as a visiting professor, the leadership of the professional course instructor, to realize the depth of the teachers and instructors.

\section{E. Professional Construction Investment System Innovation}

The food and drug safety police professional construction, to build "overpass" cooperation into the system. Actively establish deep cooperation with schools, enterprises, sharing the teachers, Shared courses, the exchange of students, teamed up with research, joint service, realize the integration of all kinds of high quality education resources. Funds to invest, also solve the laboratory equipment and testing instruments, lagging behind the problem such as simulation places, tactical training. In addition, the role of degree certificate, and gradually develop professional ability of professional certification system.

\section{CONCLUSION}

As the public security department of education, we should promote the development of education on the reform of public security, improve the quality of education on the reform of public security. Position of the public security colleges and universities should also be classified subject to emphasize on characteristic development, applied talents of public security education should be the main body of public security education. In the era of big data, we should actively 
explore the food and drug safety personnel training mode, the innovation of teaching contents, cultivate the food and drug safety police.

\section{REFERENCES}

[1] Li Chunlei. China's food and drug crimes review and preview [J]. Journal of the Chinese people's public security university, 2015 (8).

[2] Lo Binfei. Food and drug safety of social governance factors and countermeasures research [J]. Enterprise economic, 2015 (5).

[3] Zhang Qi. Our country set up the food and drug police are faced with the problem and countermeasures [J]. Railway police college journal, 2014 (12).

[4] Qiao Hui. The food and drug police system background, present situation and the international experience for reference [J]. Quality and safety of agricultural products, 2014 (8). 